\title{
ダブルフラクチャリング法による地山応力の測定
}

\section{IN-SITU STRESS MEASUREMENT BY DOUBLE FRACTURING}

\author{
佐久間彰三*・菊 地 慎二*・水 田 義 明**・世良田章正 $* * *$ \\ By Shozo SAKUMA, Shinji KIKUCHI, Yoshiaki MIZUTA and Shosei SERATA
}

\begin{abstract}
In double fracturing, in contrast to the case with hydraulic fracturing where a peak pressure appears at the point of fracture initiation, the fracture length increases with a further increases in the loading pressure beyond the point of fracture initiation. Angular distribution of tangential stress around borehole boundary then changes with the fracture length and tangential stress at the points distant from the primary fracture approaches the tensile strength there and secondary fracture initiation occurs. The double fracturing system called S-100 has already been developed by the authors, being based on the above fact. This paper describes outline of the system and demonstrates applicability of the stress determination procedure employed in the system. For the demonstration, precise elastic analyses by a Boundary Element Method, the coupled Fictitious Stress and Displacement Discontinuity Methods, were carried out for crack models in consideration of stress intensity factor at crack tip.
\end{abstract}

Keywords : double fracturing stress measurement, stress determination procedure, coupled fictitious and displacement discontinuity methods, stress intensity factor

\section{1. はじめに}

大規模な地下空洞の利用が盛んに計画されるようにな るにつれて, その調査や設計のために地圧を測定するこ とが多くなってきている．地圧の測定は古くは約 50 年 前に応力解放法を原理とするものが試みられている11. 応力解放法はその後ボーリング孔を利用する初期応力測 定，いわゆるオーバーコアリング法として，約 30 年前 から広く行われるようになった。 それ以来, 種々の初期 応力測定法が提案され，開発されてきた．最近の地圧測 定, 特に初期応力測定はボーリング孔を利用して行われ ることが多く, 大きく分けて二通りの方法で実施されて いる. 1 つは, 岩盤中に小口径のボーリング孔を削孔し て测定用の計器を挿入または埋設したり，孔壁や孔底に 貼り付けたりした後，オーバーコアリングによって地山 応力を解放する方法である. この方法は応力が解放され ることによって生ずる孔の形状の変化を，いくつかの標 点におけるひずみ, 孔径変化, 標点間距離の変化などを

* 正会員 日本国土開発（株）エンジニアリング本部 （ 107 港区赤坂4-9-9）

** 正会員 工博 山口大学教授 工学部資源工学科 （厈755 宇部市常盤台 2557）

*** Ph. D. Serata Geomechanics Inc. (4124 Lakeside Drive Richmond, CA USA)
測定することによって検出し, 岩石の弾性係数を用いて, そのような形状の変化をもたらす地山応力を逆算するも のである.

もう 1 つは, 孔壁を強制的に破壊させ, 破壊条件式か ら地山応力を決定するものであり, 流体圧で孔壁を破壊 させる水圧破砕法が広く用いられている．この方法は， オーバーコアリングを必要としないので深い位置での測 定が可能であり，直接に応力を测定しているので地盤の 変形特性を必要としないという特徴を有している.

著者らは，この水圧破砕法の特徴を取り入れた新しい 応力測定理論を構成し, 測定機器の開発を行った ${ }^{2)}$. こ の方法は, 柔軟なウレタンチューブを介して, ボーリン グ孔壁に流体圧を載荷し, 孔壁を破壊させるものである. 孔壁の破壊形態は, 地山応力状態や地盤物性に依存して いる．すなわち，地盤が軟質である場合には，載荷圧の 増加により, 孔壁はせん断降伏し, 載荷圧-孔径変化曲 線は非線形性を示すが，著者らは，数值解析やその他の 手法を用いて, この種の載荷曲線からも地山応力を算定 している3),4).

また，一般的な硬質岩盤においては，水圧破砕と同様 に, 載荷圧の増加に伴って孔壁に引張破壊を生じ，ボア ホール軸に沿った亀裂が発生する．水圧破砕法では亀裂 内に流体が浸透し，亀裂が急激に伸展するために流体圧 
が降下するのに対して，この方法ではウレタンチューブ が流体の浸透を妨げるために流体圧が降下せず，載荷圧 の増加に伴い亀裂はゆっくりと伸展し，最終的には，最 初に発生した 1 次亀裂と直交する方向に 2 次亀裂が発生 する．地山応力は，上記の 2 組の亀裂のそれぞれを発生 させる条件または再開口させる条件と実際の載荷圧とか ら逆算されるので, この応力測定法はダブルフラクチャ リング法と名付けられている. 載荷圧や孔径の変化は, 測定システムのプローブ内に設定された高精度の圧力ト ランスデューサやLVDT（差動トランス）によって計 測され, 得られた載荷曲線から, 亀裂発生時や再開口時 の載荷圧を求める.

本論文では, ダブルフラクチャリング法による応力測 定を硬質岩盤に適用する際の理論的基礎，すなわち，引 張亀裂発生後の応力変化や 2 方向の亀裂の発生過程につ いて行った解析結果について報告する.

\section{2. 応力測定理論}

ダブルフラクチャリング法は, 直接的には, ボアホー ル軸に垂直な平面内の地山応力を測定するものである が，走向・傾斜の異なる 3 本以上のボーリング孔を利用 すれば三次元応力場決定の可能性もある. 図一1に示す ように，孔軸に垂直な平面内において，地山応力場の最 大主応力を $P_{0}$, 最小主応力を $Q_{0}$ とすれば, 半径 $R$ の ボーリング孔の削孔, 孔内からの載荷 $P$ によって,ボー リング孔周辺の応力場は次のように擾乱される（圧縮が 正).

$$
\begin{aligned}
\sigma_{r}= & P \frac{R^{2}}{r^{2}}+\frac{1}{2}\left(P_{0}+Q_{0}\right)\left(1-\frac{R^{2}}{r^{2}}\right) \\
& +\frac{1}{2}\left(P_{0}-Q_{0}\right)\left(1-\frac{4 R^{2}}{r^{2}}+\frac{3 R^{4}}{r^{4}}\right) \cos 2 \theta \cdots \cdots \\
\sigma_{\theta}= & -P \frac{R^{2}}{r^{2}}+\frac{1}{2}\left(P_{0}+Q_{0}\right)\left(1+\frac{R^{2}}{r^{2}}\right) \\
& -\frac{1}{2}\left(P_{0}-Q_{0}\right)\left(1+\frac{3 R^{4}}{r^{4}}\right) \cos 2 \theta \cdots \cdots \cdots \cdots \\
\tau_{r \theta}= & -\frac{1}{2}\left(P_{0}-Q_{0}\right)\left(1+\frac{2 R^{2}}{r^{2}}-\frac{3 R^{4}}{r^{4}}\right) \sin 2 \theta \cdots \cdots(
\end{aligned}
$$

\section{Po}

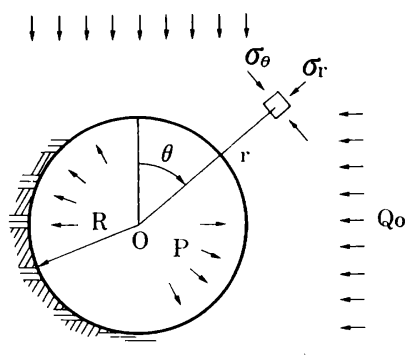

図一1ボァホール周辺の応力状態

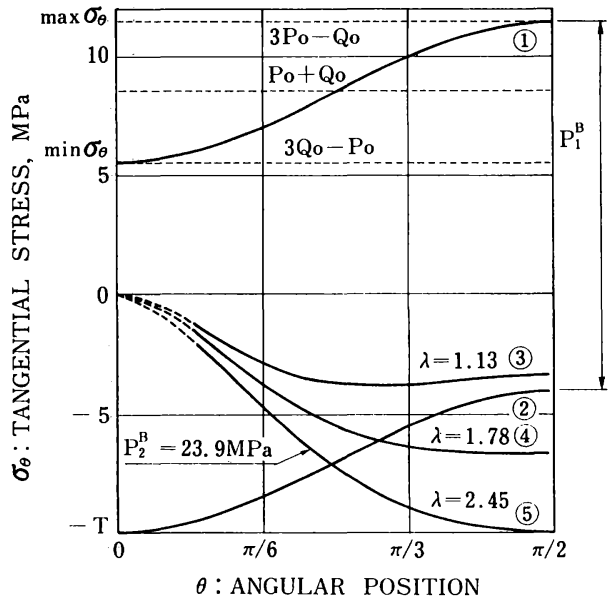

図一2 載荷圧の增大に伴う接線応力分布の変化 $(T=10 \mathrm{MPa})$ ただし $P_{0}=5 \mathrm{MPa}, Q_{0}=3.5 \mathrm{MPa}, R=0.05 \mathrm{~m}, K_{1 c}=0.5 \mathrm{MPa}$. $\mathrm{m}^{1 / 2}, P=0 \sim 23.9 \mathrm{MPa}$

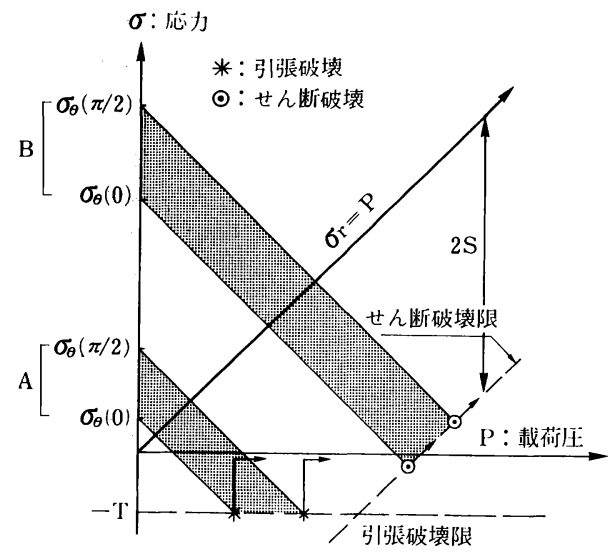

図一3 内圧の增加に伴う壁面応力の变化

ただし，図一1に示すように, $\theta$ は $P_{0}$ 方向からの角度, $r$ はボアホール中心からの距離である.したがって, ボアホール壁面 $(r=R)$ の応力成分 $\left(\tau_{r \theta}=0\right)$ は次式 で与えられる.

$\sigma_{r}=P$
$\sigma_{\theta}=P_{0}+Q_{0}-2\left(P_{0}-Q_{0}\right) \cos 2 \theta-P$

上式からわかるように，接線応力 $\sigma_{\theta}$ は $\theta=0, \pi / 2$ でそれぞれの最小, 最大となり, その応力分布は $P$ の 増大に伴って図一2 の曲線(1)から曲線(2)まで変化する. また, 内圧 $P$ の増加につれて, $\sigma_{r}$ は直線的に増加し, $\sigma_{\theta}$ は直線的に減少する. この関係を模式的に描く之図 一3のようになる. いま, 地盤の強度特性として, 引張 強度 $T$ とせん断強度 $S$ を考えよう. $\sigma_{\theta}=-T$ なる直線 を引張破壊限, $\sigma_{r}=P$ と $2 S$ 離れた直線, $\left(\sigma_{r}-\sigma_{\theta}\right) / 2=$ $S$, すなわち $\sigma_{\theta}=\sigma_{r}-2 S$ をせん断破壊限亡する. 初期 の状態 $(P=0)$ 加厣 $P$ を増加させていくと, 接 
線応力は直線的に減少し，引張破壊限またはせん断破壊 限に達し, 孔壁は破壊する. よ゙ちらの破壊限に達するか で破壊形態は異なり, 図一3の A の場合に引張破壊, $\mathrm{B}$ の場合にせん断降伏となる.

一般の硬質岩においては, 引張強度に比べてせん断強 度が大きいので, 削孔した段階で孔壁がせん断降伏して いない $\left(\sigma_{\theta}<2 S\right)$ 限り, A 引引張破壊が発生するもの と思われる. そこで, 以後の検討は孔壁が引張破壊し, 亀裂が伸展していく過程について行う.

孔壁の破壊は最初 $\sigma_{\theta}$ が小さい箇所, すなわち $\theta=0$ の位置で発生するが, 引張破壊が生じると $\theta=0$ で $\sigma_{\theta}$ $=0$ となり，次章で述べる計算によれば，たとえば図一 2 の条件においては, 応力分布(2)は曲線(3)のように変化 する. さらに内圧を増加させると， $\theta=0$ で発生した 1 次亀裂は徐々に伸展し, 応力分布は 1 次亀裂の影響を受 けながら曲線(4), (5) と変化する. やがて接線応力は $0<$ $\theta \leqq \pi / 2$ でも引張強度に達し, この位置で 2 次亀裂が発 生する.

$\theta=0$ で 1 次亀裂が発生するときの載荷圧 $P_{1}^{B}$ は, 式 (5)より，次式で決まる.

$$
-P_{1}^{B}-P_{0}+3 Q_{0}=-T \cdot
$$

亀裂が発生したときの載荷圧やそれらの亀裂を再開口 させるときの載荷圧は水圧破砕法におけるブレークダウ ンプレッシャやセカンダリィブレークダウンプレッシャ のように明瞭には検出できない，また，著者らの計測に おいては載荷速度一定としているので, その制御が正確 であればあるほど，載荷圧-時間曲線上には原理的に表 われ得ない. しかし, 圧力-孔径変化曲線からは検出で きる可能性がある.すなわち，1 次亀裂に対しては， $\theta$ $=\pi / 2$ に近い方向の孔径変化と圧力との関係から $P_{1}^{B}$ と $P_{1}^{E}$ とが検出でき, 2 次亀裂に対しては $\theta=0$ に近い方 向の孔径変化と圧力との関係から $P_{2}^{B}$ と $P_{2}^{E}$ とが検出で きる。

\section{3. 載荷に伴う内孔境界と曹裂周辺の挙動の解 析}

\section{（1） 解析プログラム}

ダブルフラクチャリング法による亀裂の発生および伸 展過程を検討するために境界要素法を用いた応力解析を 行った. 三次元応力場において, 主応力の方向がボアホー ル軸に対して傾斜している場合でも，最初に孔壁から発 生する亀裂はボアホール軸に沿ってできることが確かめ られている. そこで, 解析は二次元問題として行ってい る. ボアホール境界面は, $n$ 個に分割された仮想応力 (応 力不連続) 要素で表わされる. 一方, 内圧の増大による 亀裂の伸展をモデル化するために，1 次亀裂に対して $n$ 個の変位不連続要素を導入し,それぞれの要素を組み合

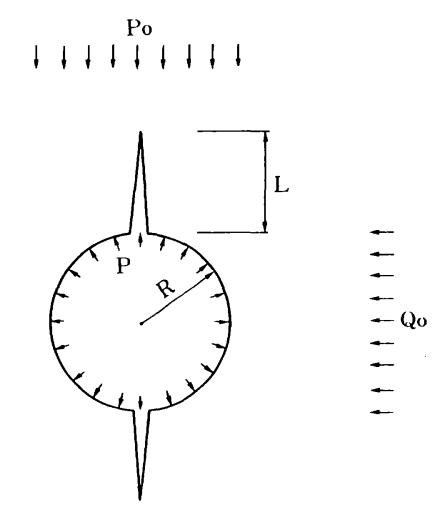

図一4解析モデル

わせている.

このような組合せ解析の手法については, Crouch and Starfied ${ }^{5)}$ によって詳しく述べられているので, こ こでは省略する.

\section{（2）亀裂の伸展による応力分布の変化}

上記の境界要素法を用いて, 亀裂の伸展によるボア ホール周辺応力の変化を求めた. 亀裂の発生する条件之 しては, 地盤応力が地盤の引張強度を越えた場合とし， 1 次亀裂の伸展には, 応力拡大係数の概念を用いた. す なわち, 亀裂先端の応力拡大係数が地盤の破壊靶性値を 越えた場合に亀裂が伸展するものとした。

解析モデルは, 図一 4 に示すように半径 $R$ のボアホー ルに最大, 最小主応力 $P_{0}, Q_{0}$ と内圧 $P$ が作用し, $P_{0}$ 方向に亀裂が伸展していくものとする. ボアホール壁面 の応力は, その位置と亀裂の長さの関数となり, 次式で 表わされる.

$\sigma_{\theta}=A(\lambda, \theta) P+B(\lambda, \theta) Q_{0}+C(\lambda, \theta) P_{0}$

$A, B お よ ひ ゙ ~ C$ は, 亀裂長さ $\lambda$ のモデルにそれぞれ $P$, $Q_{0}$ および $P_{0}$ の単位載荷を行ったとき, $\theta$ の位置に生ず る $\sigma_{\theta}$ 值であって, 弾性論から導かれるものである. ま た $\lambda$ は 1 次亀裂の長さ $L$ とボアホール半径 $R$ との比で ある。

$P, Q_{0}$ および $P_{0}$ のそれぞれの単位載荷が作用してい る場合の亀裂の伸展に伴う応力分布の変化を図示すると 図一5のようである. 図からわかるように, 1 次亀裂の 伸展の影響を大きく受けるのは，亀裂と垂直な方向の地 山応力成分 $Q_{0}$ に対する応力係数であって, $P_{0}$ に対する 亀裂の影響は小さい.この図から得られる $\theta=\pi / 2$ の位 置での応力係数に与える亀裂の伸展の影響を図一6に示 す. 図からわかるように， $P_{0}$ に対しては，亀裂が伸展 してもほとんど影響を受けず, $C(\lambda, \pi / 2)$ はほぼその ままであるが, $B(\lambda, \pi / 2)$ は大きく引張側に変化する. そしてこのことが, 亀裂の伸展に伴って, $\theta=\pi / 2$ また はその近傍の位置での 2 次亀裂の発生を促している. 

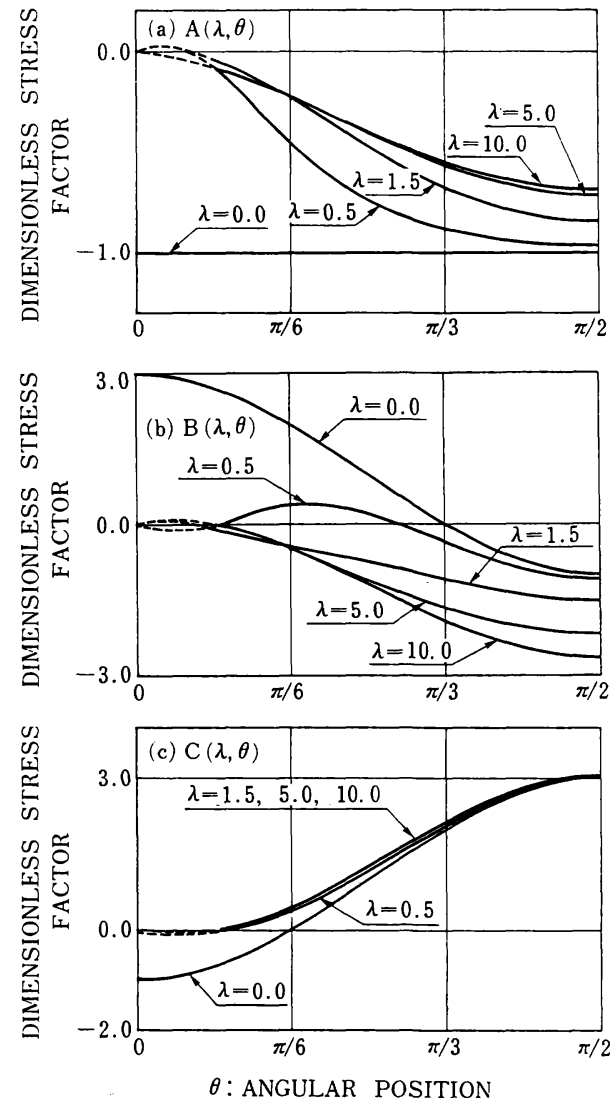

図一5 㫣裂伸展に伴う応力分布の変化; ( a ) $P$ の単位載荷, （b） $Q_{0}$ の 単位載荷, (c) $P_{0}$ の単位載荷

亀裂先端の応力拡大係数 $K_{1}$ は次式で与えられる.

$K_{1} / \sqrt{R}=K_{A}(\lambda) P+K_{B}(\lambda) Q_{0}+K_{c}(\lambda) P_{0}$

それぞれの係数は, $\lambda$ の関数で, 亀裂の変位から次式 により計算される6).

$$
K_{x}=\sqrt{2 \pi} \frac{1}{4\left(1-\nu^{2}\right)} \cdot \frac{V_{x}}{\sqrt{r}} \text {. }
$$

ここに,

$V_{x}:$ 亀裂先端から $r$ の位置の亀裂の開口変位

$x: P, Q_{0}$ および $P_{0}$ の 3 種類の単位載荷に対するも のの 1 つを表わす.

\section{$r:$ 亀裂先端からの距離}

\section{$\nu:$ ポアソン比}

実際に, 数値解析から得られるのは亀裂先端近傍の変 位であるから，変位外挿法を用いて亀裂先端部の応力拡 大係数を計算した. このようにして求めた応力拡大係数 の無次元化係数を図一7に示す.この図から， $\lambda=2.0$ 以上になると応力拡大係数に及ぼす $P_{0}$ の影響はほとん ゼなくなることがわかる．また， $Q_{0}$ の影響は大きく， 亀裂の伸展を抑えるように作用している。

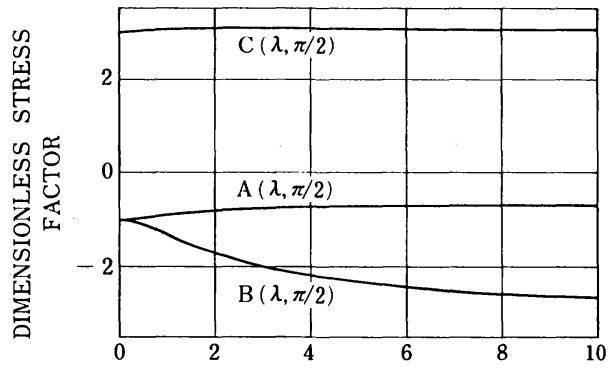

$\lambda$ : DIMENSIONLESS CRACK LENGTH 図一6 愚裂伸展に伴う応力係数の変化

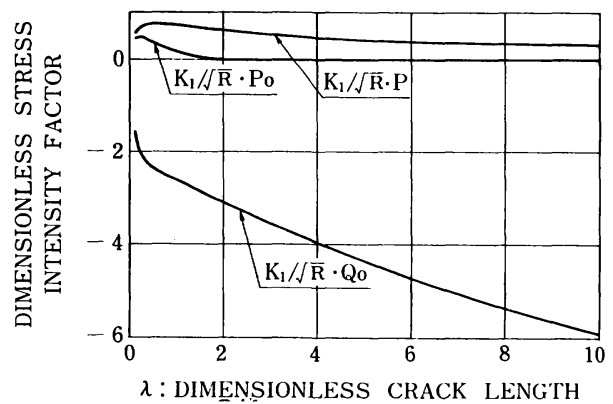

図一7裂伸展に伴う応力拡大係数の变化

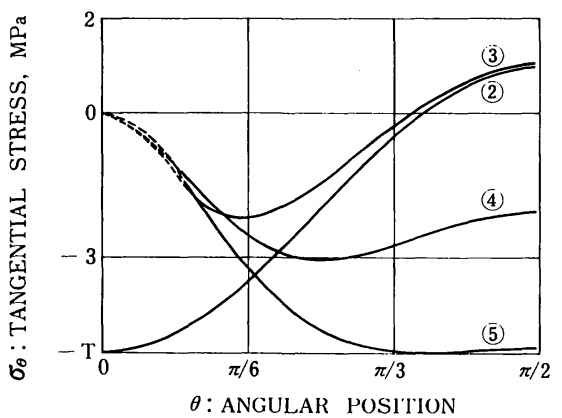

図一8 載荷圧の增大に伴う接線応力分布の变化 $(T=5 \mathrm{MPa})$ ただし $P_{0}=5 \mathrm{MPa}, Q_{0}=3.5 \mathrm{MPa}, R=0.05 \mathrm{~m}, K_{1 c}=0.5 \mathrm{MPa}$. $\mathrm{m}^{1 / 2}, P=10.5 \sim 17.4 \mathrm{MPa}$

\section{（3） 2 次亀裂発生位置}

2 次亀裂発生位置は次のものに関係する.

1) 最大主応力 $\quad P_{0}$

2) 最大 $\cdot$ 最小主応力比 $k=Q_{0} / P_{0}$

3）岩盤の引張強度 $T$

4）岩盤の破壊勒性値 $K_{1 c}$

ダブルフラクチャリング法による載荷過程を境界要素 法を用いて解析し, 上記の項目の影響を検討する. 解析 条件は, 次のように設定した。 また, 引張強度は 2 ケー スを考えて引張強度の影響を求めた。

ボアホール半径 $\quad R=0.05 \mathrm{~m} \quad(\phi 100)$

最大主応力 $\quad P_{0}=5 \mathrm{MPa}$ 


$\begin{array}{ll}\text { 最小主応力 } & Q_{0}=3.5 \mathrm{MPa} \\ \text { 引張強度 } & T=5 \mathrm{MPa}, 10 \mathrm{MPa} \\ \text { 破壊靶性値 } & K_{1 c}=0.5 \mathrm{MPa} \cdot \mathrm{m}^{1 / 2}\end{array}$

前述の図一2 は $T=10 \mathrm{MPa}$ の場合の載荷圧の増大に 伴う接線応力分布の変化を示したものである. また， $T$ $=5 \mathrm{MPa}$ の場合のそれは図一8に示されている，当然 のことながら 1 次亀裂は $P_{0}$ の方向 $(\theta=0)$ で発生し, このときの載荷圧は式（6) より計算できる.すなわち,

$$
T=10 \mathrm{MPa} \text { のとき } P_{1}^{B}=15.5 \mathrm{MPa}
$$$$
T=5 \mathrm{MPa} \text { のとき } P_{1}^{B}=10.5 \mathrm{MPa}
$$

このときの応力分布が図一2 と図一8 の曲線(2)である. $\theta=0$ で亀裂が発生した後, 亀裂先端の応力拡大係数 が破壊靶性值に等しくなるまで亀裂は伸展する． $T=$ $10 \mathrm{MPa}$ の場合の上記の載荷圧における亀裂の伸展長は $L=5.6 \mathrm{~cm}(\lambda=1.13)$ と大きく, そのため応力分布も 大きく変わる.これが前述の図一2 の曲線(3)である.こ れに対して, $T=5 \mathrm{MPa}$ では $L=1.5 \mathrm{~cm}(\lambda=0.3)$ 程 度と小さく, 図一8 の曲線(3)に示されるように, $\theta=$ $\pi / 2$ での応力変化も小さい.さらに載荷を増大させると, 亀裂が伸展しながら応力は引張側へ変化する．この変化 の大きさは図一 8 においても $\theta=\pi / 2$ で最も大きい（曲 線(4)).

さらに載荷圧を上昇させると，図一 2 では $\theta=\pi / 2$, 図一 8 では $\theta<\pi / 2$ の位置で接線応力が引張強度に達す る (曲線(5))。このときの載荷圧, 亀裂長, 亀裂発生位 置を表一1 に示す. $T=10 \mathrm{MPa}$ の場合には応力分布が 1 次亀裂の影響のため, 完全に逆転し, $\theta=\pi / 2$ で 2 次

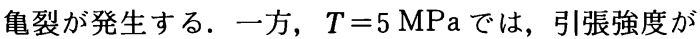
小さいために, $\theta=65^{\circ}$ で 2 次亀裂が発生する。 なお, 2 次亀裂が発生するときの 1 次亀裂の伸展長は, $T=$ $10 \mathrm{MPa}$ で約 $12 \mathrm{~cm}(\lambda=2.4)$ である.

図一7からもわかるように，亀裂がどれほど伸展する かは, 破壊靶性值のほかに, 孔径や亀裂長の絶対值にも 関係する. しかし，無次元化された 1 次亀裂の長さ $\lambda$ と無次元化された孔壁接線応力の最小值 $\min \sigma_{\theta} / P_{0}$ お よび無次元化された応力拡大係数 $K_{1} / \sqrt{R} \cdot P_{0}$ との間の 関係はそれぞれの絶対值が何であろうと成立する．そこ で次に, 単位半径 $(1 \mathrm{~m})$ のボアホール, 地山応力の 最大主応力が単位の大きさ $(1 \mathrm{MPa})$ のモデルについて 2 次亀裂発生位置の検討を行った。
地山応力状態として, 最大 ・最小主応力比 $k$ を次の ように仮定した。

$k=0.1,0.2, \cdots \cdots, 0.9$

また $P_{0}$ 方向からの角度 $\theta$ を次のように設定し,

$\theta=30^{\circ}, 40^{\circ}, \cdots \cdots, 90^{\circ}$

種々の長さに仮定した 1 次亀裂の長さに対して, 上記の それぞれの角度 (位置) で接線応力が最小となるような 載荷圧を求めた。

求められた載荷圧から接線応力と応力拡大係数を算定 し， 1 次亀裂長との関係をプロットすると， $k=0.8$ の 場合，図一9のようになる．図一9から，ただちに，1 次亀裂の伸展長が長くなるにつれて, $\theta=\pi / 2$ で 2 次亀 裂が発生するときの接線応力が小さくなることがわか る.また， 1 次亀裂がボアホール半径分伸展した場合に，
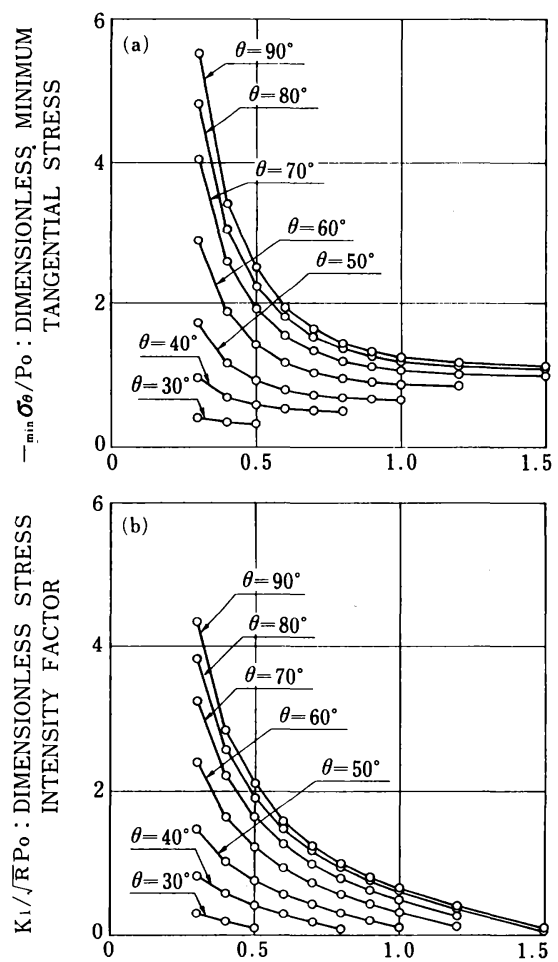

$\lambda$ : DIMENSIONLLSS CRACK LENGTH

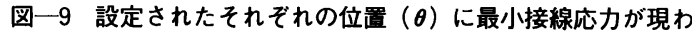
れるときの，(a) 最小接線応力および（b）1次黾裂 先端応力拡大係数, と暳裂長の関係

表一1＼cjkstart境界要素法による計算結果一筧

\begin{tabular}{|c|c|c|c|c|c|c|}
\hline \multirow{2}{*}{$\begin{array}{c}\text { 引張強度 } \\
\stackrel{T}{(\mathrm{MPa})}\end{array}$} & \multirow{2}{*}{$\begin{array}{c}1 \text { 次亀裂発生時 } \\
\text { の载荷压 } \\
(\mathrm{MPa})\end{array}$} & \multicolumn{3}{|c|}{ 2次亀裂発生時の } & \multicolumn{2}{|c|}{ 简易式により算定された } \\
\hline & & $\frac{\text { 載荷压 }}{(\mathrm{MPa})}$ & $\begin{array}{c}P \text { 1次亀裂長 } \\
(\mathrm{cm})\end{array}$ & $\begin{array}{l}\text { 龟裂発生位置 } \\
\left({ }^{\circ}\right)\end{array}$ & $\begin{array}{l}\text { 最大主応力 } \\
\text { Po (MPa) }\end{array}$ & $\begin{array}{l}\text { 最小主応力 } \\
\text { Qo ( } \mathrm{MPa})\end{array}$ \\
\hline 10.0 & 15.5 & 23.9 & 12.0 & 90.0 & 5.9 & 3.8 \\
\hline 5.0 & 10.5 & 17.4 & 7.0 & 65.0 & 5.3 & 3.6 \\
\hline
\end{tabular}


$\theta=\pi / 2$ で最小となる応力值は $\sigma_{\theta}=-1.25 P_{0}$ である. したがって，このような 1 次亀裂の伸展が考えられる場 合には，地盤の引張強度が最大主応力の 1.25 倍以上あ れば $\theta=\pi / 2$ で 2 次亀裂が発生する. 一方, 1 次亀裂長 が 0.6 より小さい場合には, $\theta=\pi / 2$ の位置に最大の引 張応力が現われるときの応力が急激に大きくなる．した がって，このような場合でも $\theta=\pi / 2$ で 2 次亀裂が発生 するためには，地盤が大きな引張強度を有していなけれ ばならない.

以上のことから，1 次亀裂の伸展の大きさは地盤の引 張強度や破壊䩲性值に関係し，伸展が大きいほ亡゙ 2 次亀 裂の発生位置は $\theta=\pi / 2$ に近づく，図一10 は，図-9を 整理して応力拡大係数と引張接線応力最大值との関係を 示したものである. この図から， $K_{1 c} / \sqrt{R} \cdot P_{0}=0.5$ の 場合， $k=0.8$ では $T=1.2 P_{0}$ 以上であるとき, 2 次亀 裂は $\theta=\pi / 2$ の位置に発生することがわかる.

\section{（4）亀裂再開口時の載荷圧を用いた応力算定}

ダブルフラクチャリング法で地山応力を算定する 1 つ の方法として, 1 次亀裂と 2 次亀裂が発生する場合の載 荷圧を用いることが考えられる．また，その場合でも， 用いられる方程式は簡単である方が望ましい。そこで, 2 次亀裂が発生する直前の応力分布に 1 次亀裂の影響が ないとして, すなわち, 式（7）において $A=-1, B$ $=-1, C=3$ とおいて算定された地山応力が表一1 に示 されている.これをみると， $T=10 \mathrm{MPa}$ の場合には， 最大主応力で $18 \%$ 程度大きく算定される. また $T=5$ $\mathrm{MPa}$ では，約 $6 \%$ 程度大きくなる。

一方，岩盤の引張強度， 1 次亀裂の長さおよび 2 次亀 裂の発生位置がわかると, 亀裂発生時の載荷圧 $P_{1}^{B}$ と $P_{2}^{B}$ から地山応力を算定することができる，しかし，般に岩盤は不均質であり, 強度は組織敏感性であるから, 亀裂が生じる箇所の引張強度を一意的に定めることは難 しい場合が多い。このため，著者らの通常の測定におい ては, 1 回目の載荷で 1 次および 2 次亀裂を十分に長く 伸展させ, 亀裂位置での引張強度 $T=0$ とした後, 再び 載荷を繰り返し，2 方向の亀裂がそれぞれ開き始めると きの載荷圧 $P_{1}^{E}, \quad P_{2}^{E}$ から地山応力を算定するものとす る.このとき, $\theta=\pi / 2$ の位置に 2 次亀裂が発生するも のと考え，次式を用いる.

$-P_{1}^{E}-P_{0}+3 Q_{0}=0$

$A(\lambda, \pi / 2) P_{2}^{E}+B(\lambda, \pi / 2) Q_{0}+C(\lambda, \pi / 2) P_{0}=0$

そこで，2 次亀裂の開口時の載荷圧に対する 1 次亀裂 長の影響と 2 次亀裂が $\theta=\pi / 2$ 以外の位置に発生した場 合の影響について検討した。ただし 1 回目の載荷で亀裂 が発生した位置での地盤物性は次のように仮定した。

引張強度 $\quad T=0$

破壊靭性值 $K_{1 c}=0$
解析は, 主応力比（側圧比）を種々仮定し, 種々に設 定された位置 $(\theta)$ で接線応力 $\sigma_{\theta}=0$ となり，かつ 1 次 亀裂先端の応力拡大係数が $K_{1}=0$ となるような載荷圧 を求めた。図一11に 2 次亀裂が開口するときの載荷圧 と側圧比との関係を示す。またこの図には，1 次亀裂の 影響がないもの（式（7）において $A=-1, B=-1$, $C=3)$ として計算した場合の 2 次亀裂再開口時の載荷 が破線で示されている．このような簡易式と式（10）と から地山応力を算定した結果が表一2に示されている.

ダブルフラクチャリング法による載荷では, $\theta=0$ と $\theta=\pi / 2$ の両方で亀裂が入ることが期待されている. ま た,この 2 つの亀裂の再開口時の載荷圧から地山応力を

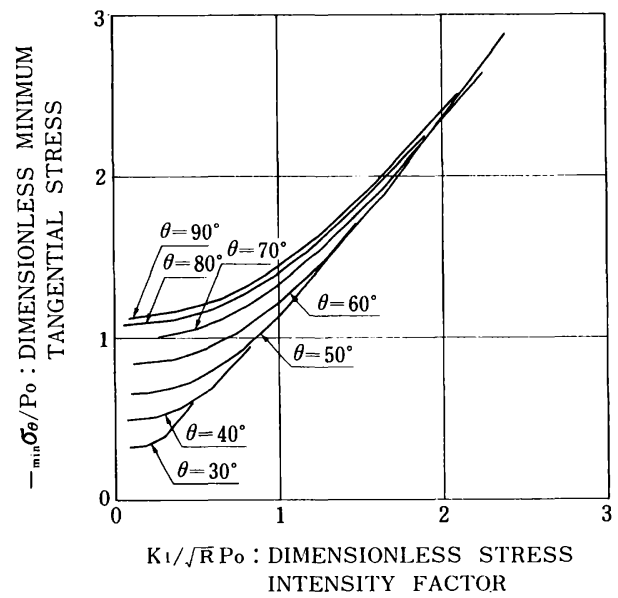

図一10 設定されたそれぞれの位置（日) に最小接線応力が現 われるときの最小接線応力と応力拡大係数との関係 $(k=0.8)$
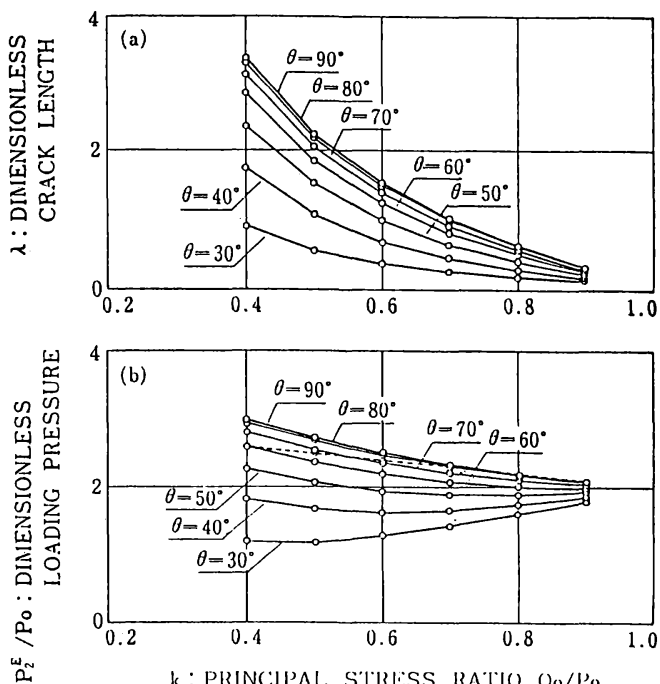

図一11 2 次愚裂再開口時の，（a）1 次奄裂開口長および （b）載荷圧，と側圧比の関係 
詳細に決定するためには，接線応力に影響を与える 1 次 亀裂の開口長さを求めなければならないが，2 次亀裂が 開口する瞬間の 1 次亀裂の開口長さは, 図一11を利用 すれば, $k$ と $P_{2}^{E}$ および $\lambda$ との関係から逐次近似的に $\lambda$ を決定することができる．実際，著者らは，地下 1000 $\mathrm{m}$ の $k$ が非常に小さい地点において，このような方法 で地圧計測を行った．また，このときには三次元応力場 の決定も試みている7!.

しかし，表一2に示すように，1 次亀裂開口長の影響 を無視した簡易式によって応力を算定しても， $k=0.5$ 以上であれば, 最大 $8 \%$ 程度の誤差しかない.したがっ て, 主応力比が異常に大きなところでなければ, 式 (7) の代わりに次の簡易式を用いてもよいと思われる.

$$
-P_{2}^{E}-Q_{0}+3 P_{0}=0 \text {. }
$$

また，表一 2 には 2 次亀裂が $\pi / 2$ 以外の位置に発生し た場合に，式（12）を用いて応力を算定した結果も合わ せて示されている。これをみると， $\theta=50^{\circ}$ の位置に 2 次亀裂が発生した場合には，ほとんどのケースで $10 \%$ 以上の誤差が認められる.さらに， $\theta=30^{\circ}$ では，かな り大きな誤差を伴って応力が算定される.しかし， $\theta=$ $60^{\circ}$ 以上の位置に 2 次亀裂が発生した場合には, 誤差は $8 \%$ 以下である. したがって, $0.5<k<1$ かつ $60^{\circ}<\theta$ $<90^{\circ}$ であれば, 式 (13) を用いても十分な精度をもっ て応力を算定できると思われる.

\section{4. 測定システムの概要}

このような載荷圧の増加による孔径の変化を測定する
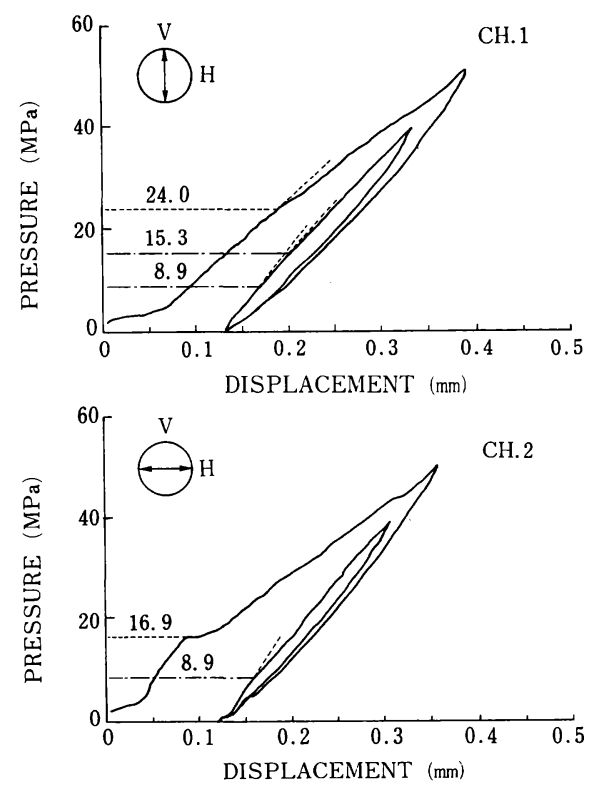

ために，プローブには $45^{\circ}$ 間隔に LVDT が配置されて いる. したがって，4方向で検出された孔径変化と圧力 之の関係，すなわち 4 種類の圧力-変位曲線が得られる ことになる. 図一12 は次章で述べる現場検証試験から 得られた一例で,このような図から亀裂が発生および再 開口したときの載荷圧を読み取るわけである.

\section{表一2 簡易式を用いた場合の応力算定}

\begin{tabular}{|c|c|c|c|c|c|c|}
\hline \multirow{2}{*}{ Qo/Po } & \multirow{2}{*}{$P_{1}^{E}$} & \multirow{2}{*}{ 項目 } & \multicolumn{4}{|c|}{ 二次き裂の発生する角度 $\theta\left({ }^{*}\right)$} \\
\hline & & & 30 & 50 & 70 & 90 \\
\hline \multirow{3}{*}{0.4} & \multirow{3}{*}{0.2} & $\mathrm{P}_{2}^{E}$ & 1.160 & 2.260 & 2.794 & 2.975 \\
\hline & & Po & 0.46 & 0.87 & 1.07 & 1.14 \\
\hline & & Q० & 0.22 & 0.36 & 0.42 & 0.45 \\
\hline \multirow{3}{*}{0.5} & \multirow{3}{*}{0.5} & $\mathrm{P}_{2}^{\mathrm{E}}$ & 1.156 & 2.073 & 2.555 & 2.715 \\
\hline & & Po & 0.50 & 0.84 & 1.02 & 1.08 \\
\hline & & Qo & 0.33 & 0.45 & 0.51 & 0.53 \\
\hline \multirow{3}{*}{0.6} & \multirow{3}{*}{0.8} & $P_{2}^{E}$ & 1.264 & 1.948 & 2.363 & 2.511 \\
\hline & & Po & 0.57 & 0.83 & 0.99 & 1.04 \\
\hline & & Qo & 0.46 & 0.54 & 0.60 & 0.61 \\
\hline \multirow{3}{*}{0.7} & \multirow{3}{*}{1.1} & $\mathrm{P}_{2}^{\mathrm{E}}$ & 1.419 & 1.896 & 2.224 & 2.344 \\
\hline & & Po & 0.67 & 0.85 & 0.97 & 1.02 \\
\hline & & Qo & 0.59 & 0.65 & 0.69 & 0.71 \\
\hline \multirow{3}{*}{0.8} & \multirow{3}{*}{1.4} & $\mathrm{P}_{2}^{\mathrm{E}}$ & 1.602 & 1.901 & 2.124 & 2.212 \\
\hline & & Po & 0.78 & 0.89 & 0.97 & 1.00 \\
\hline & & Q0 & 0.73 & 0.76 & 0.79 & 0.80 \\
\hline \multirow{3}{*}{0.9} & \multirow{3}{*}{1.7} & $P_{2}^{E}$ & 1.800 & 1.943 & 2.056 & 2.102 \\
\hline & & $P_{0}$ & 0.89 & 0.94 & 0.38 & 1.00 \\
\hline & & Qo & $0.8 \mathrm{G}$ & 0.88 & 0.89 & 0.30 \\
\hline
\end{tabular}
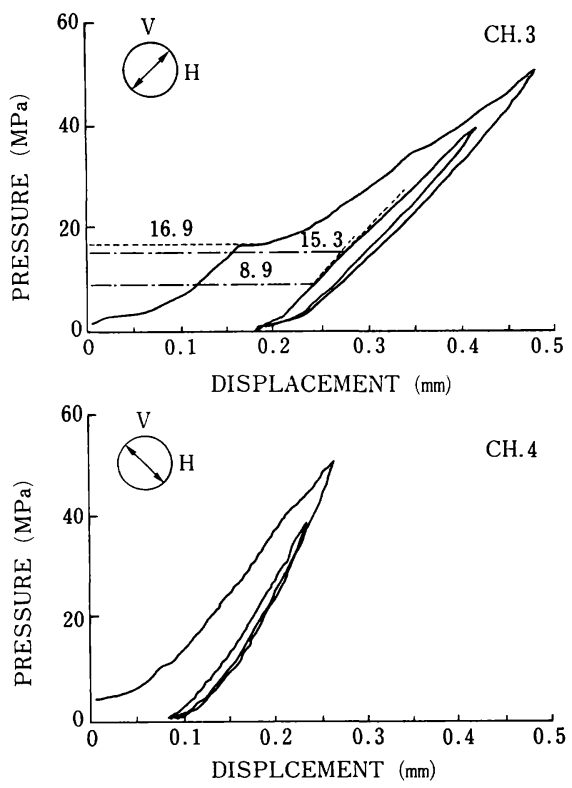

図一12 現場実証試験における載荷曲線から検出された（1次および 2 次）串裂発生時と再開口時の載荷圧 
図からわかるように，2 つの亀裂の発生時や 1 次亀裂 再開口時の載荷圧は曲線の偏向点として比較的明瞭に読 み取られるが，2 次亀裂再開口時の偏向点は，2 次亀裂 の長さが十分でないために，このままでは判定できない 場合も多い，そこで，2 次亀裂再開口時の偏向点は，繰 り返し載荷を数多く行うなど載荷方法を工夫したり，図 を拡大するなど読み取り方法を工夫したりして検出を 行っている.

一方, 孔径変化量は, 最大主応力方向において最も大 きく, 最小主応力方向において最も小さいので， 4 方向 の孔径変化から $P_{0}$ と $Q_{0}$ の方向を推定することができ る.また， $P_{0} ， Q_{0}$ の方向をより明確にしたい場合には， 同じ位置でプローブを回転させて計測すればよい。

測定システムS-100（図一13）は，プローブ（S-100 本体), 油圧載荷装置, デー夕収集装置 (DDR-200) お よびデータ解析用コンピュータ（HP-87）で構成され ている.

測定ではプローブを測定位置に設定後, まず, 油圧載 荷装置（電動油圧ポンプ）から油圧ホースを経てプロー ブに油圧が供給され，プローブの載荷部が膨張してボー リング孔壁に到達し，加圧されていく．このときの圧力 とボーリング孔の変位量はセンサーで感知されコント ロールチャンバー内の電子回路に送られて信号処理され た後, 電気ケーブルを介してデータ収集装置 (DDR-200) に転送される。この信号は $\mathrm{A} / \mathrm{D}$ 変換されて DDR-200
内のメモリーチップに集積される．測定データは，現場 で DDR-200 とパーソナルコンピュータを接続してパソ コンへ転送し，デー夕編集後に図化処理される．また， フロッピィディスクへ記録される.

図一14にプローブの断面模式図を示す. S-100 プロー ブの特徵は, 載荷部のウレタンチューブに 4 個の LVDT を取り付け, 孔径変位量を直接測定している点

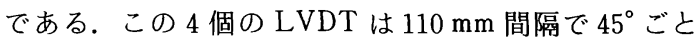
に方向を変えて配置されており，前述のように個々の LVDT ごとに独立した圧力-変位の関係を得ることがで きる.

エンドキャップは, 載荷部であるウレタンチューブと 非載荷部との境界にあり, ウレタンと金属の剛性の違い に起因するウレタンチューブの破損を防ぐ構造となって いる.このエンドキャップが約 $70 \mathrm{MPa}$ という高圧載 荷を可能にさせている.

\section{5. 現場検証試験}

ダブルフラクチャリング法による応力測定は, 1983 年加ら本格的に開始し，室内実験や現場実験による検証 を行うのと並行して種々の岩盤での実測に適用してき た. 本論文では理論解析から得られた亀裂伸展・発生条 件と現場検証実験において観察された結果との比較検討 を行うことにする。

検証実験においては，1 次亀裂の伸展長さや 2 次亀裂

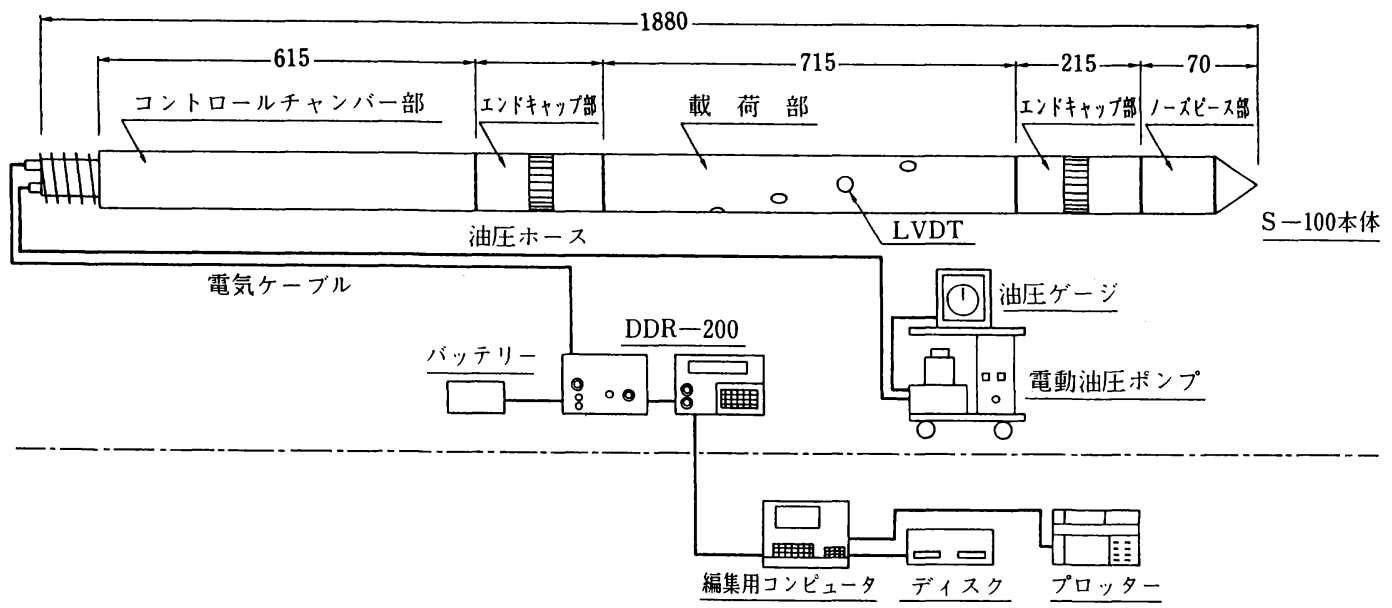

図一13 測定システム構成の概要図

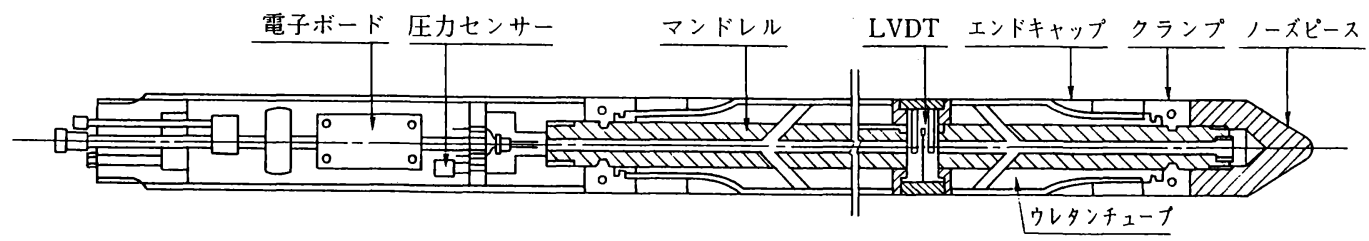

図一14 プローブ断面図 
の発生位置を実際に観察するために，かなり均質な岩盤 を利用して載荷実験を行った後に, 大口径のオーバーコ アリングを行った. ボーリングは地下の坑道内から水平 方向に行った. 以下に実験の手順を示す.ただし, 通常 の測定手順は(1)－(5)であって，手順(6)と(7)は亀裂検証の ために特に実施されたものである.

(1) 空洞壁面より径 $100 \mathrm{~mm}$ の水平ボーリングを行 う.

(2) コアの観察から既存亀裂状況を把握する.

(3) 型取りチューブを取り付けたプローブを挿入し, 低圧で既存亀裂の型取りを行い，既存亀裂の確認 を行う。

(4) 再び型取りチューブを取り付けたプローブを挿入 し，載荷試験を行う。

(5) 型取りチューブを取りはずし, 載荷によって発生 した亀裂の確認を行う.

(6) 径 $480 \mathrm{~mm}$ のオーバーコアリングを行い，載荷試 験筒所のコアサンプリングを行う.

（7) 載荷試験によって発生した 1 次，2 次亀裂の確認 を行う.

コアの観察や事前の型取りチューブの結果から，実験 筒所の岩盤は, 既存亀裂が少なく, かなり均質なもので あった，室内実験から得られた岩石の強度は, 次のよう であった。

\section{一軸圧縮強度 $Q_{u}=84.3 \mathrm{MPa}$}

圧裂引張強度 $T=8.0 \mathrm{MPa}$

破壊䩲性值 $\quad K_{1 \mathrm{c}}=0.71 \mathrm{MPa} \cdot \mathrm{m}^{1 / 2}$

載荷後の型取りチューブから， $P_{0}$ 方向の亀裂（1 次 亀裂）は大きく, 明瞭に判別できるが, 2 次亀裂は小さ いため, 型取りチューブで検出するのは困難であった.

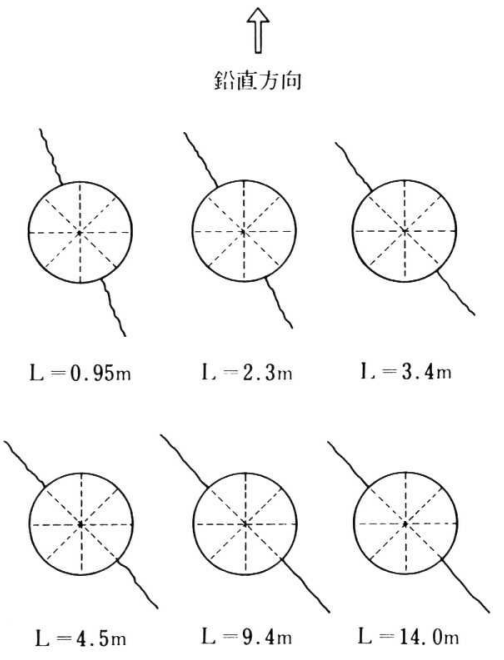

図一15 実証試験における 1 次黾裂の方向 ( $L$ : 坑道壁面からの距離)
ボーリング孔の各深度で検出された 1 次龟裂の方向を図 -15に示す. 1 次亀裂の方向は, 最大主応力方向を表 わしている. 坑道の影響が少ないボーリング孔深度の データから主応力方向を求めると, 鉛直より左側に $45^{\circ}$ 傾いた方向で, どの深度でもほぼ一致している. 一方, 坑道壁面に近づくにつれて最大主応力は鉛直方向に傾い てくる.これは, 坑道の影響で坑道断面の接線応力が集 中しているためと思われる.

亀裂の確認のために径 $480 \mathrm{~mm}$ のオーバーコアリング を行った. 写真一1にコアを輪切りにして, 亀裂状況を 観察した結果を示す. 1 次亀裂は大きく, オーバーコア を貫通している.これに対して，2次亀裂は小さく，ボ アホール半径の 2 倍程度の長さとなっている. また, 写 真左側の 2 次亀裂の発生位置は, 1 次亀裂から $90^{\circ}$ の方 向であり, 右側の 2 次亀裂は, 若干はずれたものであっ た.

この位置で得られた載荷曲線はすでに図一12に示さ れている. 1 次亀裂や 2 次亀裂の再開口圧は, 次のよう になる。

$$
\begin{aligned}
& P_{1}^{E}=8.9 \mathrm{MPa} \\
& P_{2}^{E}=15.3 \mathrm{MPa}
\end{aligned}
$$

これより，簡易式を用いて応力を算定すると最大，最 小主応力 $P_{0}, Q_{0}$ は次のようになる.

$$
P_{0}=6.85 \mathrm{MPa}
$$$$
Q_{0}=5.25 \mathrm{MPa}
$$

1 次亀裂の発生時の載荷圧 $P_{1}^{B}=16.9 \mathrm{MPa}$ から引張 強度を算定すると,

$T=16.9-8.9=8.0 \mathrm{MPa}$ となる.

これは, 岩石の圧裂引張強度と同じ値であり,ここの 岩盤は, 既存亀裂が非常に少ないことがわかる.

また, 2 次亀裂の発生時の載荷圧 $P_{2}^{B}=24.0 \mathrm{MPa}$ から 引張強度を算定すると,

$T=24.0-15.3=8.7 \mathrm{MPa}$ となり, 1 次亀裂の值から 算定した値より若干大きな值を示している.これは 1 次

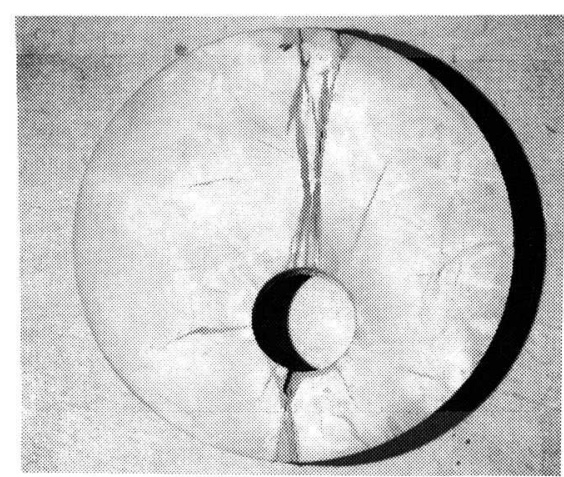

写真一1 オーバーコアによる奄裂の観察 
亀裂の伸展に伴う応力分布変化の影響を受けたためと思 われる.

なお，この実験において 1 次亀裂を伸展させ得るとき の無次元化された応力拡大係数は, $K_{1 c} / \sqrt{R} \cdot P_{0}=0.46$ である. また $k=0.77$ であり, 2 次亀裂を発生させ得 る接線応力は， $T / P_{0}=1.17$ であるから，図一13 上り， 2 次亀裂は $\theta=\pi / 2$ からいくらか傾く可能性もあること がわかる.

\section{6. ま と め}

地山応力の測定方法として, 種々の方法が開発, 改良 される中で, 多少の亀裂性岩盤や軟岩に適用でき, 比較 的深い深度においても測定できることを目的としてダブ ルフラクチャリング法の開発を行ってきた.この方法は, 孔壁の亀裂に流体が浸透しないようにチューブを介して 流体圧を作用させると互いに直交する 2 方向の亀裂が発 生することに注目している，また，あらかじめ岩盤を破 壊させることによって, 応力の算定時には不均質な岩盤 の物性をできるだけ取り入れないように工夫し，応力算 定の精度を高めるようにした。さらに, LVDT や信号 処理システムの開発を行い, 精度の良い載荷曲線が得ら れるようにした。

一方，この応力測定法の基本原理である互いに直交す る 2 方向の亀裂発生については, 理論解析から, 岩盤の 引張強度がある程度大きければ成立すること，また，1 次亀裂に対してたとえある程度傾いて発生しても，あま り問題にならないことなどを確かめた．さらに，原位置 試験後の大口径オーバーコアリングにより, 実際の 1 次 亀裂の伸展状況および 2 次亀裂の発生条件が解析結果と 調和的であることを確かめた。

また， 1 次亀裂の開口長増大による応力係数の変化に 基づく誤差は地山主応力比が極端に小さい場合などの特 殊な条件を除けば, それほど大きくないことも確かめた。 さらに，そのような特殊な条件下でも，解析結果に基づ く逐次近似を行えば，問題なく地山応力を算定できるこ
とを示唆した. なお，異なる方向のボアホールが 3 本以 上あれば，三次元応力場の決定も不可能ではない.

現在, システムのレベルアップを行うとともに, 大梁 度に適用できる機器の開発を行っており, 今後はさらに 精度が高く, 容易に多量のデータが得られるような計測 システムと確立していくつもりである.

謝 辞: 本研究を始めて以来, 終始山口大学工学部 建設工学科教授 中川浩二博士にご指導とご鞭撻を頂い た. 実証実験の坑内現場は住友セメント（株）小倉事業 所に提供して頂いた。また, 現場の岩石の破壊䩲性值の 試験は徳山工業高等専門学校講師 橋本堅一氏にお願い した.ここにこれらの各位に謝意を表する.

\section{参 考 文 献}

1）J. タロブル：岩盤力学, 森北出版, 昭和 42 年 2 月.

2）菊地慎二, ほか：孔内載荷システムとコンピュータを利 用した岩盤の応力測定, 第 16 回岩盤力学シンポジウム, 昭和 59 年 2 月.

3）菊地慎二・中村哲也：岩塩鉱山における原位置応力と物 性の計測例, 第 6 回岩のカ学シンポジウム, 昭和 59 年 12 月.

4) Serata, S. and Bellman, Jr. R.A. : Development of the SERATA Stress-Measuring System for Application to Both Hard-Brittle and Soft-Ductile Grounds, 24th U.S. Symposium on Rock Mechanics, 1983.

5) Crouch, S. L. and Starfield, A. M. : Boundary Element Methods in Solid Mechanics, George Allen \& Unwin, 1983.

6）石田 誠: き裂の弾性解析之応力拡大係数, 培風館, 昭 和 56 年.

7) Mizuta, Y., Sakuma, S., Katoh, H. and Kikuchi, S. : Stress and Stress Change Measurements by Hydraulic Fracturing and Double Fracturing for Safe Underground Excavation, 2nd Work Shop on Hydraulic Fracturing Stress Measurement, 1988.

(1988.6.11・受付) 